\title{
平安・室町時代貴族住宅の「二階」について THE BUILDING “NI-KAI" IN THE ARISTCRATIC RESIDENCE FROM HEIAN TO MUROMACHI PERIOD
}

\author{
溝口正人* \\ Masato MIZOGUCHI
}

\begin{abstract}
From Heian to Muromachi period the building called "ni-kai" was built in the aristcratic residences. The architectual style and the spatial characteristics of "ni-kai" are analyzed in this paper.

From the instances described in the ancient dairies and the archives in Heian, Kamakura and Muromachi period, it is concluded that "ni-kai". in the aristcratic residence was the facility for enjoying fine view and the events of amusement in the garden. Its architectual style was not of ordinary twostoried, but of elevated main floor.
\end{abstract}

keyrords: ni-kai, trostoried building, aristcratic residence, Heian period, Nuromachi period 二階、二陼建築、貫族住宅、平安時代、室町時代

\section{1.はじめに}

鎌倉時代までの日本建築には、金閣や銀閣をイメージ の基本とするような楼閣建勧の明確な類例がるられない 点、そしてその積極的な導入の契機として、鎌倉時代以 降の禅宗寺院建築の影響が多大であった点についてが、 太田博太郎氏により考察されている゙”。

太田氏も指摘するように、古代の寺院建築の塔や金堂 においてみられる重層構成は、外観の意近的なものに留 まり、人が利用可能な空間 (室空間)としての二階は存 在しない。少なくとも現存遣構で判断する限り、金閣や 銀閣のような上下階ともに利用可能な室空間を伴なう二 階建築あるいは楼閣建築の住宅への導入の契機を、禅宗 寺院建築における二階建築の導入に求めることについて は、広く認められている2)。また画像史料としては、古 くは楼閣建筑の実在性の有無に関する話題を提供した唐 戸・鍵道跡出土土器片に描かれた建策画や、長屋王㿟宅 跡出土の「楼閣山水之図板絵習書」にも二階建てに類す る建筑が描かれている。しかしそれらが太田氏が述へる
ような室空間としての二階を伴なった楼閣建築の存在を 示すものかについては明確ではない。

一方太田氏も言及されるように、鑛倉時代以前の文献 史料には「二階」あるいは「二階屋」と記された住宅建 築の事例が存在する。太田氏はこれらを金閣や銀閣のよ うな楼閣建築に類するものとしたうえでい、それらを特 殊なものとしで、、広くは流布しなかったとした。しか しながら特殊であろうとも、史料上に「二階」と記され た事例が存在するとすれば、それは二階建築あるいは楼 閣建築の流布を祄宗寺院建築の影蠁に帰結させる上で、 看過できない問題といえよう。また従来の研究では、文 献史料にみられる「二階」あるいは「二階屋」という語 句の意味する建築形態に対しての十分な検討は行われて こなかった。同様に「楼閣」建築と「二階」建築が同一 視できるものかについても検討の余地を残している。 そこで本研究では、平安時代から室町時代初期におけ る文献史料にみられる住宅建築の「二階」「二階屋」の 事例を取り上げて、そこにみられる建築形態や用途につ

\footnotetext{
* 修士 (工学) M. Eng.
} 
いて検討し、二階建築の形態的イメージについて再整理 を試みたい。本稿ではまず住宅における「二階」の事例 について検討する。

「二階」あるいは「二階屋」と記述される建策には、 様々な態様があり得る。一般的に、「二階」という語か ら想定される建築形態には、一。二階共に室空間を伴な い、空間的な二層構成が考えられるが、この他にも外镜 のみの二階。二重棧成であり、室空間としての二階が存 在しないるの、あるいは室空間としての一階を伴わず、 望楼建築（物見台）のように、床が通常の二階レベルと 認識されるような高休建筑が考えられよう。以下本文で は、これらの建築の総称として二階建築という語を用い ることとしたい。

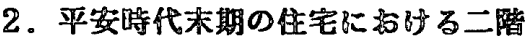

以下、文献史料に記䟿された住宅における「二邽」の 建筑形態についての洘察を中心に進めていくが、まず最 初に、禅宗寺院建築における二階建築の等入以前となる 平安時代末期の琵例を取り上げる。

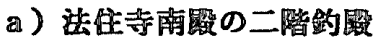

太田静六氏が言及されたように5)。『兵範記』 安 3 年 (1168) 8月 4 日绦（高倉天皇朝覞行幸時）により。 法住寺殿における「二階验殷」の存在が知られる。それ は同記に「三階验恧上東西二面格子、西 [南加］北二面

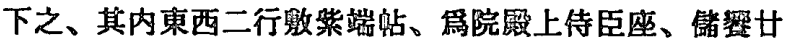
前（院庁令弁備之）」（下缐策者、以下同じ）と記され

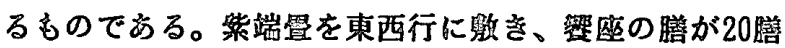
設けられたところからみて、東西に長い建䥼であったこ とになる。

当日然の記事によれば、菒中門㰾南端にあったとみら

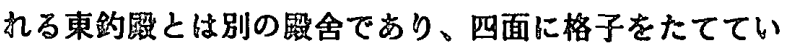
たとみられるから、独立した倠舍であったと挎えられる。 また太田静六氏の教察にあるように。中島南に存在した

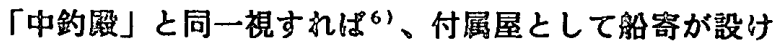
られるような規模が想定される。『兵範記』記事には、 殹上侍臣座となった階以外についてなんら言及しない。 釣䂑という名称からみて、その建等形態は室空間として の一階を伴なわない高床型であった可能性が高い。

この二階的㚿の記事は安 2 年 (1167) の移徙以降で ある。上安 2 年の改造は、察殿の变更にまで及ぶ大規模 なるのであったことが明らかにされており、この二階验 䝘の存在が応保元年 (1161) の新造移徙時点にまで邀る のか、あるいは安 2 年に新造されたものであるのかは 明らかではない。応保元年度の䬺舍構成を示すとされる 『年中行事絵巻』には描かれていない7。

b) 源定游三条亭の二階御所

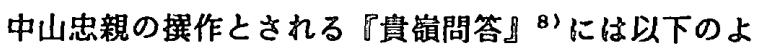

うに記される「二重舎屋」あるいは「二階御所」の存在 が知られる9。

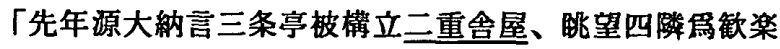
所、回程之後踓有造作之事、今度無其屋、件楼者、暑月 納涼尤有便宜、欲構立此蓬屋如何、可被計示之状如件、 三階御所事、京中猶屬目骺、営䋨令日、私第宅皆不得起 楼閣臨観人家者、此事非稳便骺、仍言上如件」

源定房（1130１188）101 の三条亭には「二重舎屋」 と記される建策が存在したという。そして後述する安元 3 年 (1177) 4 月28日の太郎嬅亡で、定房の三条亭も被 害に邀い、「二重舎屋」も焼失したのである。その後、 邱宅の再建に当って、「二階御所」建造の可否を問われ た忠親は、次稿でも述べる『営縉令』の私第宅楼閣禁止

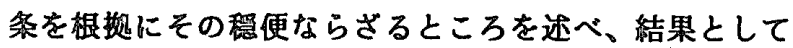
そ㣗は再建されなかった。

文中では「二重舎屋」と「楼」とを同義、また「二階 御所」むほぼ同義としており、『営綪令』の「楼閣」に 相当するとしている。「二重」と記するから。あるいは 空間的な二層構成であった可能性もあるが。『令義解」 に説く「楼者、重屋、閣亦楼也」との記述を受けての表 現であり、単に外躀上の二重を示しているとる考えられ る。「二階」の「御所」との記述からは、眺望や納涼を 目的とする二階を主体とした物見栈䁶的な建筑とみられ、 この点で形態的には高床型と考えるのが妥当であろう。 また庭園に関係した建築であり、「歓楽所」とされるよ う行会所的遊翼施設と考えられる。また「蓬屋」と記さ れるから、草䡃。照木造といったような、通常の住宅建 筑と異なった意匠が想定される。

この三条亭の位置については明確ではないが、『葉」 太郎䈂亡当日条には「恅亡所々…源大納言（在西京云々、 当時不居住彼之家也）」之記するから、西京の三条近辺 となる。あるいは『源平盛衰記』11に記される「良相 公ノ西三条」か「高明御子ノ西宮」に比定されるものと 考えられよう ${ }^{121}$ 。䅧失当時は定房常住の邱宅ではなか ったのであるが、その位置や、遊整施設としての二階御 所の存在から考えると、庭園を主体とした遊整目的の別 壮的性格を持っ㿟宅であったともみられる。

\section{c）砅通光久我亭の二階之台閣}

『明月記』建永元年（1206）8月19日条には「両少将 清簛季能等招引、乗月向左衙門督久我亭。…亭主出透。 昇三階之台閣、望田野月非無興、亭主琵琶。雅少将吹策 策、具少将笛、出題詠三首歌、鵎鳴㷌」之記され、䝠通 光の久我亭での「二階之台閣」の存在が知られる。

久我亭は鴨川と桂川の合流点の久我に位置し、村上愿 氏の祖、䃇師房が別邱を営んだことに始まる。その後に 源影房の所領として「久我水閣」とも記され ${ }^{131}$ 、以後、 雅実を経て村上源氏の洛外御所として用いられている。 師房以後の造営については明らかではないが、通光の父 
通親の時代の久我亭の様子が、通親作の『秝香山模草堂 記』(以後『草堂記」と記する）により知られる ${ }^{14) 。 ~}$ 文治 2 年 (1186) 頃の制作と比定される『草堂記』には 15)、通親が久我亭を伝領して後、寿永 3 年（1184）頃 の久我亭の様子について以下のように記する。

「長元六年夏、䡆相右丞相、…作為媧舎、雖非燕漫、高

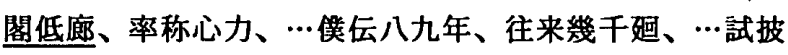
草堂記、忽模竹墙様、広荥不過三間、豊殺又以方丈、桂 柱非影、石階以礎、湛藍滛水、開白蓮池、々中立竹台、 々南渡松橋、環崖多青田、…夾谷有翠松…遂明年林鐘之 末、草堂新成、‥於新堂招河南元集、四月九日也」

この記述によれば、通親の造作により文治 2 年頃に新 堂が建立された。また新堂完成以前、通親伝領時の久我 亭には、黒木造ともいうべき意匠の住居、庭園の池、そ の中島と思われる位置に「竹台」、その南に架けられた 「松橋」が存在していたという(6)。またこれら草庵的 な意匠の建築と、渓谷には田が開かれ松が生えるといっ た田園風景と合わせて、久我亭は洛外御所としての㔀び

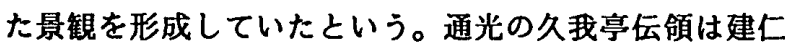
2 年 (1202) の通親死去によるものと考えられるが、通 光伝領以後の久我亭の造作については確認されない。

「草堂記」の記述は、「二階之台閣」が存在した時点で の久我亭の殷舍構成に比定できるであろう。

「明月記」によれば、久我亭における「二階之台閣」 は、奏楽や和歌会が行われる会所的な性格を持つ遊繁施 設であり、眺望や観月を目的とした高い床レベルを持つ 建筑であったといえる。具体的な形態について明らかで はないが、これら記述内容における「二階」の「台閣」 という語からは、二階の室空間を主体とした高床型の建 築が想定されるであろう。少なくとも主たる室空間とし ての下階は存在していなかった可能性が高い。

またその機能は観月・眺望の場であるとするから、庭 園に関係した建築である。「草堂記」に記する施設では

「竹台」がそれに比定できよう。そうであれば竹を用い た数寄建築ともいうべき意匠であったことになる。建贸 そのものが遡るのかは不明であるが、「草堂記」に師房 造営時の建築構成として記された「高閣低廊」の「高閣」 に相当するものとも考えられる。

久我亭は、「草堂記】の「踓非燕寝」という記述が示 すように、師房造営時から居住というょりは洛外におけ る遊銶を目的とした別萑として造営されたものであり、 通親や通光の時代でも、その性格が踏襲されていた。黒 木造、竹台、松橋といったような、通常の住宅建築と異 なった意匠の建築の存在は、まさに遊业・数寄空間とし ての久我亭の性格によるものといえよう。そして「二階 之台閣」は、そのような空間的性格を有する久我亭にお ける遊喰施設のひとつだったといえる。

\section{d）福原の平清盛㥸の二階栈敷层}

『平家物語』巻七には、以下のような福原の平清盛邸 の記述に「二階の栈數殿」の存在が記される ${ }^{171 。}$

「故入道相国の造りおき給ひし、春は花見の岡の御所、 狄は月見の浜の御所、雪の御所、壼の御所とてみられけ り、馬場殿、三階の栈敷殿、・.いつしか三年に荒机はて て、…台かたぶいて荅むせり」

福原の平清盛邸は、安 4 年（1169）3月20日には後 白河上皇の御幸を受けるような施設として、その存在が 知られる ${ }^{18)}$ 。承安元年 (1171) の上皇御幸時には船遊 びを行なうような庭園が存在していた ${ }^{19)}$ 。「平家物語」 は丰永 2 年 (1183） 7 月25日時点での清盛邸を描写した ものとなるが、二階の栈敷殿は、岡の御所 ${ }^{201}$ 、浜の御 所、雪の御所といった四季をつかさどる御所、咺御所、 馬場殿とともに、清盛邱の構成要素とされている。

「平家物語」は同時代の一次史料ではなく、成立時期 が下るとされ、諸本間に記事の異同も多い。しかし上皇 の御幸を受けるような庭園が存在した清盛邸の施設とし て、望御所、馬場殷と並んで、その多くに共通して記さ れている「二陵の栈敷殿」の存在の可能性はある。少な くとも鎌倉時代における二階建築のひとつのイメージを 表したものとみることはできよう。

この記述からは「二陼の栈敷殿」の具体的な建築形態 については明らかではない。しかし「二階」の「栈敷臤」 という名称からは、物見栈敖的な「二階」を主体とする 高床型の建築が想定される。あるいは㑯いて苔むしてい たという「台（うてな）」がそれに相当するものとも考 えらよう。馬場殿や亘御所の、遊整・数寄建筑としての 存在については既に指摘されている ${ }^{211}$ 。それら殿舍と 共に記述される、「二階の栈敷殷」は、庭園における眺旺 を目的とした遊鉒施設として位置付けられているといえ る。またここに描かれた福原宮の清盛邸は、同時代の院 御所や洛外御所と同様に、遊餐施設を伴なう構成として 記述される。それは当時の社会の頂点に位置する貴族註 宅の普遍的なイメージを示したものとも考えられる。

\section{3. 鎌倉末から室町時代の住宅における二階}

禅宗寺院における上下階に空間を伴なう空間的な二層 構成の二階建築の存在は、既に鎌倉時代よりみられる。 元弘元年 (1331) の裹書を持つ建長寺指図によれば、方 丈には得月楼と命名された二階が存在し ${ }^{221}$ 、その他に も山門などにも同粎な構成と考えられる殿舍がみられる。 また室町時代には足利義淽の北山第における舎利殿（金 閣）のように、住宅にも多層構成の事例がみられる。し かしながら二階の事例がすべて二層構成の形態であるか 否かについては検討が必要であろう。以下、住宅におけ る二階建築の事例を取り上げる。 
a）北山㹂（西園寺）の二階

北山殿は、西園寺家の菩提所として公経の手により元 元年（1224）12月に完成となった、洛外の別萑的性格 とを合せ持った䄮宅である。本堂西園寺を始め、多くの 仏堂が庭園を中心に建てられた。また池や滰の配される 庭園が優美であるのみならず、都を遠く望むその眺望が 特筑的であったという231。また西園寺の北方には寝殿 があり、公経の居所とされた ${ }^{24) 。 ~}$

鏻倉末期には、実兼が持明院統の後伏見院の外成とな ったため、後伏見院以下の北山殿への度々の御幸、行幸 が行われた。そのため『花園天皇宸記』（以下『宸記』 之記する）には北山殿に関する記述は多い25)。そして 太田氏や川上氏が言及されたように261 、北山殿におけ る「二階」の存在が記される。『辰記』に記された北山 殿の「二階」は以下の 3 例である。

・元応元年 (1319) 10月18日条

「直至西園寺、南庭方歷覽、 $\cdots$ 於北面方実衡卯等参、 $\cdots$

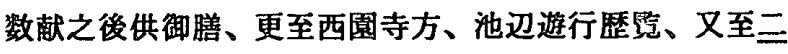
階方、及深更歷覽、雪月興計会」

- 元応 2 年 4 月 17 日条

「今日御幸北山第、眹同参、先於女院御方御対面、其後 南庭方并三階方御歴覧、於北第、入道相国参、御対面良 久、其後於南有盃的事、及日没乗船」

。元亨 3 年 (1323) 11月26日条

「急幸北山第、於忽門内、令宣衡告右大将可馳馬之由、 …即大将踦馬侯御共、....所々歷覽、…堂方御歴擥、降地

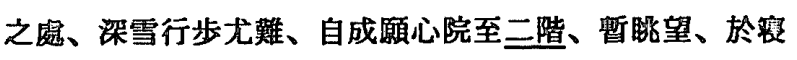
殿南面供酒兽」

当時の北山澱は、実兼やその蛝永福門院の御所として 用いられている ${ }^{27)}$ 。邱内は大きく北第と南第に分れ、 それぞれが居住施設や仏堂を伴ない構成されていたよう である ${ }^{28)}$ 。そして元応元年条の記事にみられるように、 西園寺は、主として南方の池を中心とする庭園の中に営 まれていた ${ }^{291}$ 。池では度々船遊びが行われており ${ }^{301}$ 、 そのほとりには釣殿があったという311。「二階」は、 この庭園の一郭に位置していたとみられ、「池辺遊行歴 覽、又至二階方」あるいは「南庭方并二階方御歴覧」と 記されるから、南庭からはやや離れた位置であったと考 えられる。元亭 3 年条に上れば、䅡雪時に、地面へ降り ずに成願心院から二階へ行くことができたというから、 この二つの殿舍は廊等で溳がっていた可能性が高い。

この「二階」は元亨 3 年条に記されるように、そこか らの眺望を目的とする眐舍であり、元応元年条によれば、 そこでのなんらかの会が行われたようでもある。この点 で既述の二階の系譄に則るものともいえるが。その具体 的な建筑形的は明確ではない32)。

b ) 二条家押小路䀦の二かい

二条良基の作とされる『おもひのままの日記』の以下
の記事によれば ${ }^{331}$ 、摄関家である二条家の押小路殿に 「二かい」が存在したとされる。

「六月廿日ころ、いとあつき比なれば、いずみもてあそ び給うとて、二条の家に行幸有 ${ }^{34)}$ 。御かたたがひのよ しなり。…東にたかき松山あり。山のふもとよりわきい づる水のながれ、松のひびきをそえていとすずし、水の うへに、三かいをつくりかけたれば、やがて座の中をな がれ行石間の水、さながらそでうつばかりなり。ながれ の末のすがた、入汇々々にしまじまのたたずまる。いと おもしろく、西のながれのす急に、山を隔て五尺ばかり の滰落たり。澺のうへにつくりかけたる三かいのさまな ど、山里めきていとおかしう見ゅ」

この記事によれば、押小路殿の庭園建築として、東の 松山より涌き出た流れの上に「っくりかけた」「二かい」 と、その流れの末の滝に「っくりかけたる二かい」が存 在したという。内容からみてこの 2 例は別建物とみられ るが、造水の上、あるいは滰の上に作り措けたるのであ り、流水を楽しむための栈敨的な性格の建築と位置付け られるであろう。前者は『春日権現絵巻』に描かれた藤 原俊盛邸の泉殿とされる殿舍のように 空き、建物の下を通り抜ける流水がみられるような構成 であったとみられる。また「山里めきていとおかしう見 ゆ」とされた後者の場合、いわゆる数寄屋的な意匠であ ったとも考えられよう。いずれにしろ、その設置形態か らみてこれらの「二かい」は、室空間としての下階は存 在していなかったと考えられる。二階建築としては、高 休建築に属するものといえよう。

押小路殿は、二条家祖の良実以来、二条家の本亭とさ れた的宅で、押小路南・室町東に位置する ${ }^{36)}$ 。後鳥羽 院政下、泉が涌出したことに伴ない院御所として整備さ れ、以来その庭園により知られた存在であった。室町時 代に入っても文和 2 年 (1353) 6 月 6 日に後光厳天皇の 行幸を受けるなど37、、その位置付けについては変わっ ていない。『空華日用工夫略集』（以下『日工集』と記 する）によれば良基の代に整備が行われたようであり、 庭園を中心とした良基時代の施設構成については以下に 挙げる『日工集」の記述に詳しい。

-康暦 2 年 (1380) 8 月 8 日条 ${ }^{38)}$

「八日赴二条殷倭漢連句会、入西門延視泉園池亭水石、 其美不可勝言、名其池日龍躍、記実也、此者当昼有龍羁 雨下之变、日御树閣、天子所生榻在焉、日洗孯亭、日聴 松亭、日藏春閣、日緑楊橋、日政乎水、日镜魚台、日古 霊泉、日水明楼、日梅香軒、既而准后出、接余於水亭、 互叙久渴之懐、引入御榻閣、偻漢連句百韻」

。康暦 3 年 9 月 25 日条

「甘五日過二条准后、謝昨日不赴会之意、准后引入御榻 閣対談、及古今倭漢詩文日、…准后又求余名新楼、且日 旧名十境、其政乎水、則月中岩所名也、水明楼則先皇睗 


\section{名、親御宸翰云」}

これらの記事によれば、押小路段には当時の禅宗寺院 や足利将軍䄮同様、趣向を凝らした庭園空間に十境が命 名されていた。建筑的には同一殿舍のものがあるとも考 えられるが、康暦 2 年条によれば施設として御㛫閣、洗 暑亭、聴松亭、蔵春閣、観魚台、水明楼、梅香軒、水亭 の名が挙げられている。3 年条によれば、水明楼は後光 笽天皇の命名になるものであり ${ }^{391}$ 、またこの前後に

「新楼」が建造されたという40)。後円融天皇所生にち なむ楊が置かれていた御㛫閣は、両例とも倭漢連何会の 会場として用いられており、会所的施設といえる。

ところで『宸記』元広元年 (1319）7月29日条の以下 の記事により、押小路殿には既に鎌倉時代末から、これ ら二階に相当する泉屋の存在が知られる。

「院御幸二条前関白押小路亭、爲泉辺納涼也、如法密々、 非御幸儀、…到押小路亭、前関白寄御車、即步泉亭、下 車後頃之雑談、…有暫退出、有小弓弓場、仍被召御弓、 但即供有物之間不及射之、一献後召禅閤、即参、数献及 乱会、諸人銘酊、…禅閣銘百之余落縁、公秀楖取揚之、 …泉屋上所照唐絵両三対、院御方被召之、花瓶香植等同 被召之」

泉辺での納涼を目的として押小路殿へ御幸した後伏見 上皇と花園上皇は、まず泉亭で歓談、その後弓場で小弓 を行ない、その後また場を移して酒宴となった。禅閤兼 基が縁から落ちたという酒宴の場は明確ではないが、泉 亭とは別な場のようである。そして前関白道平から上皇 人、「泉屋上所」の舗設装束が贈呈された。「泉屋上所」 とは、文字通り泉屋の上った所とされよう。下階の存在 は明らかではないが、泉亭という目的から考えると、こ の殿舍の形態は高床状のものであった可能性が高い。そ して御幸に当って、後述する喫茶之亭と同様な唐絵三対 や花瓶香妯等で舗設されたという。数寄座教ともいうべ き性格の殿舍であったといえ、それが既に鏮倉時代末に 存在していたことになる。

「おむひのままの日記』に記された「二かい」がこれ らのいずれに該当するのかは明確ではない。東の松山の 流れに設けられた「二かい」が聴松亭、滝の上の「二か い」が洗暑亭か水明楼に比定されるともいえ、あるいは 水亭や新楼がそれらに該当するとも考えられる。いずれ にしても、これら庭園建築のうちのいずれかが、高床型 の形態を示しており、それが「二かい」として認識され ていたといえよう。そして押小路殷でのこのような二階 建築の存在は、鎌倉時代末にまで遡るのである。

\section{c）『唤茶往来」の喫茶之亭}

室町時代初期の作とされる「契茶往来」には41)、当 時の茶会の様子と共に二階の栈敖を持っ「奇殿」の存在 が記される。

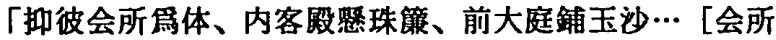

で三献・食事の後]、其後起座退席、或対北空之築山、 避暑於松柏之陰、或臨南軒之飛泉、披橴於風水之原、爱 有奇殿、峙栈墽於二晆、排眺望於四方、是則䒜茶之亭、 対月之砌也、…客位之胡休敷豹皮、主位之竹倚臨金沙、 加之處々障子、飾種々唐絵、…西廂前置二対之飾棚、而 皘種々珍菓、北壁下建一雙之屏風、而構色々鮕物…会衆 列座之後、亭主之息男献茶菓、… [闘茶が終り] 調美有、 勄酒飛盃、…式歌式舞、増一座之興、又絃又管、駡四方 之聴」

これによれば、会所で三献・食事の後、休㲘を経て、 庭園内の契茶之亭での闘茶、酒宴、歌舞管弦となった。 座の舗設は中国趣味に彩られたもので、室周囲の障子に は唐絵が髠けられ、西庇前には飾り棚、北壁の前に立て られた屏風の下には朢物が積まれている。そこでは狂喜 乱舞の酒宴が繰り広げられており、バサラともいうべき 遊慜性の強い閍茶の一場面が示されている。

「爱有奇殿」以下の部分の記述によれば、喫茶之亭は 庭園内の独立した殿舍である。闘茶の会場となった栈敷 は、文中の表現を借りれば、そびえたつ二階で四方に眺 望が開け、観月の場でもあったという。この二階の栈敷 は北壁や庇が存在し、周囲には障子がたてられてた。ま た周囲を眺望できたというから、あるいは四周に縁がま わる望楼的構成であったとも考えられる。栈敷について の詳細な記述の一方で、下階の存在についてなんら言及 されない点からみれば、少なくとも主たる室空間として の下階が存在しなかった可能性が高い421。二階の栈敨 を主空間とした高床型の建築形態が想定されよう。

また一方でそれは奇殿と記されるから、このような形 態は新奇性に富むものとみられていたともいえる。意匠 的にも他の建築とは異なった、数寄屋建築ともいうべき ものであったとも考えられよう。

d）九条段の二階

『後思眜記」応安 3 年（1370）8月15日条には「今日 未終刻雷雨、消肝、後聞、雷落九条前関白亭二階、件日 絾賞良辰、於二階有連歌会之最中霹霞云々、青侍二人爲 雷公披震死了…雷公落人家事、希有事也、可恐々々」と 記し、九条前関白経教亭に二階が存在したとする。

九条前関白亭とは、鎌倉中期以降の九条家本的となっ た九条富小路殿を示すものと考えられるが431、この九 条殷の「二階」において、連歌会が開かれていた最中に 落雷があり、死者も出たという。

ここでの「二階」の意味するところは明確ではない。 「九条前関白亭二階」と記されるから、この「文階」と は建築の室空間としての二階というよりは、二階の建築 そのものを示しているものとも考えられる。また連歌会 が開かれていたとされるから、その他の例と共通する、 会所的な性格の施設であったといえよう。 


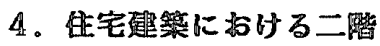

以上。平安時代末期ちよび铰倉時代末期から室町時代 の住宅における二階建筑の諸例について検討してきた。 これら二階建築は、いずれも庭園の踏望を目的とした物 見栈敫的な用途に供される庭園建筑であり、そこでは詩 歌。管弦会といった避阯が行われる会所的性格をもった 殿舍であった。そのうち少なくとも二条家の押小路㹂の 例は、明らかに高床型の形態となる。その他の例は、史 料の制約から下階の存在を完全に否定はできない。しか し詳細が不明である北山群や九条殷を除くと、源定房三

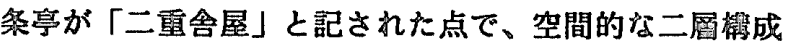
である可能性を牫しているものの、二階の根败を主体と した維成が想定される点で諸例は共通している。

これら「二階」とされた二階建築は、䁬望を目的とし て床が高く立ち上がった室笁間としての二階が主体なの であり、その場合、必ずしも下層での室空間は必要とは ならない。そこに想定される建筑形憃は、いずれる高床

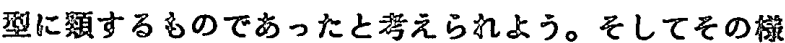
な形態や性格の二階建築が、平安時代末期から室町時代 に至るまで存在し続けていたと接えら㣗るのである。

しかしながら、「二階」と䔉現される建筑すへてに。 このような建筑形態を想定することの可否㹥。広く「二 階」の亭列它䘳討する必要がある。きたこれら二階建筑

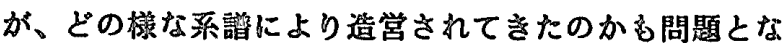
ろう。次稿ではそれらの点について梌討したい。

\section{証 記}

引用史释立中の（）括弧内は割註を。［］括旅内力夕力 ケは史科校訂、ひらがなは籍者註を示す。

1）太田博太郎「楼閣建筑に関する一坊管」『中世の建银』 部国社 $1957 \mathrm{pp} 138 \sim 145$.

2）川上貢『日本建築史资科策成』十六留院I、中央公諭 美街出版1971。解説 $\mathrm{pp} 3 \sim 4$ ．中村利則『町虽の荣室』 淡交社 1981 pp191 199.

3）太田氏は「目を一度住宅建筑に移して見ると、そこには

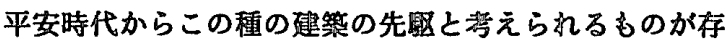
在している。」とする。

4）太田氏はこれらの專例を「し加しがらこれらの二陌屋 は比輘的简単なるのであり、かつまた特殊疗るのとして 広く用いられてはいなかったようである。」とした上で、 「二階」が纉宗寺院建築に多く見られる点に注目し、い わゆる二階建筑が禅宗建築の影楒により起ったとする。 桜井秀氏は『總合日本史大系』第四巻、内外管籍 1925. p517. において、後述する『貫碗問答』を引き、同様に 二階を特殊な㙁とする。

5）太田静六 「寝殿造の研究』吉川弘文館1987。第五章第四 節。なお太田博太郎氏前揭管においても、記事の存在に ついて言及されている。

6）太田静六氏は『王偞』安元 2 年（1176）3月 5 日条（後 白河上皇五十奉算賀）に「…於中钓殿乗船（其釣殿東面 有船寄、然而依無便宜、於南面汀乗之）」と記される中

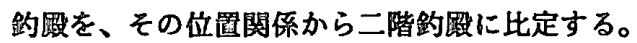

7）法住寺殿の沿革と『年中行事絵巻」との関係については、 川本重雄「法住寺殿の研究」『建筑史論譚』中央公諭美 術出版1988. による。

8) 『群害類従』巻139 所取。『群書解題』では瀷作年代を

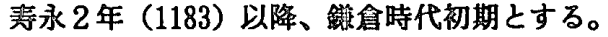

9）記專の前半部分は『古事類范』居良部に収䟿されている。

10）村上愿氏。雅兼の子で中院右大臣雅定の猶子となる。 『山媿記』や『王葉』に源大秋言之記される。永万 2 年 （1166）7月15日に権大的言、後に大种言となり以後20 余年その位にあった。

11）『塬平盛衰記』巻四による。ただし、後通する語り物乐 『平家物語』の該当部分には記されない。

12）『拾芥抄』にはそれらの位圈について、「西三条（三条 北朱墔西、良相大臣家、俗云百夜公專 [百花而加）」 「西宮（四策北朱墔西、高明御子家）」と記する。いず 礼す西京。朱雀院近辺である。

13）『中右記』貿治元年（1087）2月10日条「上皇邀攽鳥羽

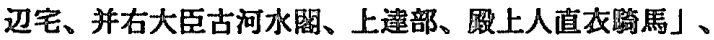

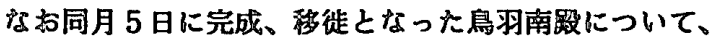
同記 5 日条に「入夜上皇初有御幸鳥羽水閣」之記する。

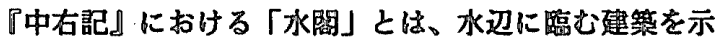
し、必ずしも二階建筑を意味しないと考えられる。

14）『㮩香山模草堂記』および白氏文集の草堂記など先行諸 作品との比較については、品川和子「擬香山橙賞堂記に ついて」『学苑』第 369 号、1970.9による。

15）『草堂記』の制作年代を。橋本義彦『䝠通親』吉川弘文 館1992. では文中「倬伝之八九年」との記述により毒永 3 年（1184）頃とする。しかし文中の後半の記述からは、 その明年に「草堂」を建立した時点ての述桑となる。品 川氏の指摘にある文治 2 年 (1186) 頃の制作とするのが 桑当である。

16）「開白蓮池、々中立竹台、々南核松橋…」の部分は『草 堂記』独自の記述であり、久我亭の実態を示するのと荐 えられる。

17）『平家物語』巻七「平家一門都落ち」条。愿童仲入京直 前琴永 2 年 (1183) 7月25日の記德である。本文は新湖

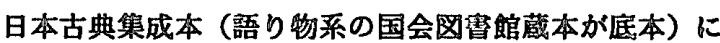
よる。読み物系に属する「䝠平盛衰記」では、同一内容 は卷三十二「福原管能讙」条に入る。なお本文捈討には この他に冨倉徳次郎『平家物語全注彩』角川望店1967、 杉本圭三郎『平家物語』偝談社学術文庫、『参考原平盛

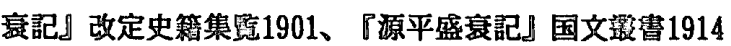
を用いた。

18）『兵䉇記』同日条。高野山御幸㫶途時の御幸である。

19）『百鉠抄」同年10月23日集「太上法皇建春門院御幸太政 大臣福原別埾、有船遊事。遊女晹禄」

20）『平家物語」巻五、物经条によれば「椆の御所」は透都 時の新造とされる。

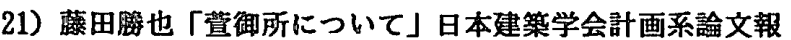
告集。第 382 号，1987.12。抽稿「平安宮 - 後院と摄関 家住宅の馬場殿 馬場殿の研究 その $1 」$ 日本建築学会 計画系論文報告集。第 446 号，1993.3

22）ただし、方丈の再建は貞治年間（1362～1367）まで下る （横山秀哉「禅の建筑」彰国社 1967。 pp78 79）。

23）『堌鏡』第五、内野の雪。仏堂としては善稓院、功徳蔵 
院、池のほとりの妙音堂、石橋の上の五大堂、成就心院、 法水院、化水院、無量光院が記される。

24）註23）「北の寝殿にぞ大臣は住み給ふ」

25）文保 3 年 (1319）正月14日の御幸を始めとする。

26）太田氏前揭查、及び川上氏前揭書pp10１1。

27）「辰記」元応 3 年 2 月19日条によれば、北山殿は永福門 院の本所御所であったという。本文元応 2 年条に記され た女院御方とは、永䄄門院御所を示す。

28）「宸記」文保 3 年 5 月 15 日条、元亨 2 年 6 月 11 日条。

29）西園寺の位圆関係について「とはずがたり」巻三には、 弘安 8 年 (1285) の北山准后九十賀宴に際して「北殿よ り西園寺へ造道を敷く。両院、…堂々御巡礼ありて、妙 音堂に御参りあり。」と記する。御所北段が賀宴会場と なり、その南方の池のほとりに西園寺他の諸堂が位置し た。この北殿と、「宸記」に記される北第・南第、ある いは「増鏡」に記する「北の漫殿」との関係は明らかで はない。

30 ) 本文引用「花園天皇宸記」元応 2 年条、元亨 3 年 9 月 12 日条及び註29）など。

31) 註29）に同じ。

32）「辰記」では元亨 3 年11月 8 日条に「二階堂」と記した 椎野の伏見院納骨堂を、元亨 2 年10月10日条では単に 「二陼」と記するから、「二陼」という語からは形態は 確定できない。なお川上氏は註26）において、「金閣の 構想の一半に二階殿が大きく参考になったと思われる。」 とする。

33）「群書類従」巻第489 所収。底本は一条兼実自筆本であ る。「群書解題」によれば、康暦〜永徳年間（1379～13 83）の成立かとされる。記述事柄からみて成立時期はや や下ると考えられるが、内容の矛盾は見られず、成立は 同時代として妥当である。なお「おもひのままの日記」 の制作年代と制作者については別稿としたい。

34）管見の限りでは、貞治元年（1362）から正長元年 (1428)
までで該当する行幸は確認されない。註37）に述へるよ うに、定式化していた行幸であったとも考えられる。

35）太田静六氏前揭書p882

36）押小路殿の伝領については高群逸枝「平安鎌倉室町家族 の研究」国書刊行会1985による。

37）「園太暦」同日条「今暁寅刻許行幸埶柄押小路亭、当代 初度行幸也」。後光䭛天皇は前年 8 月17日に践稂した。 「当代初度行幸也」との記述から、押小路殿への行幸が 定式化していたものとも受けとれる。

38）延文 4 年（1359）に足利基氏の招きにより鎌倉に下って いた義堂周信は、この年に足利義满の招きに応じてほぼ 20年ぶりに上洛した。文中に記述によれば、この記事は、 以前から親交を結んでいた良基の招待で押小路段を訪れ た時のものである。

39）前出文和 2 年行幸時の命名の可能性が高い。

40）康暦 2 年条に記する「水亭」がそれに該当するものとも 考えられる。

41）「群書類従」所収。「庭訓往来」の作者として知られる 玄恵法印（～1350）の作とされるが明確ではない（「群 書解題」による)。茶会の記述内容から室町時代初期と するのが通説である。

42）中村氏は註 2）において、北壁の存在や唐絵を障子に惩 ける埔設から闘茶の場の開放性に疑義を持たれ、「その 二階というのは単なる望楼であり、規模もさほど大きく なかったのではないだろうか。そしてその一階に茶璗の 場が設けられていたと考えたほうがよさそうである。」 とする。しかし文意からみて、䦥茶の場は二陵とみるの が自然である。単に北壁の存在などから二階の「喫茶之 亭」を二層型建築と想定した上で、一階の存在を比定す ることには問題を残す。

43）高群氏前揭曹による。位置は九条北富小路西あたりと考 えられるが明確ではない。

（1993 年 6 月 10 日原稿受理, 1993 年 12 月 27 日採用決定） 